UDC 613.2:613.956:614.72:616-092.11-02

DOI: $10.21668 /$ health.risk/2021.2.07.eng

Research article

\title{
A SYSTEM FOR CREATING HEALTHY LIFESTYLE IN EDUCATIONAL ESTABLISHMENTS AS A WAY TO PREVENT HEALTH DISORDERS IN CHILDREN
}

\author{
V.V. Vasilyev ${ }^{1,2,3}$, M.V. Perekusikhin ${ }^{4}$, E.V. Vasilyev ${ }^{5}$ \\ ${ }^{1}$ Penza State University, 40 Krasnaya Str., Penza, 440026, Russian Federation \\ ${ }^{2}$ The Penza Institute for Doctors' Advanced Training, a brunch of Russian Medical Academy for Continuous \\ Occupational Training, 8a Stasova Str., Penza, 440060, Russian Federation \\ ${ }^{3}$ N.N. Burdenko's Penza Regional Clinical Hospital, 28 Lermontova Str., Penza, 440026, Russian Federation \\ ${ }^{4}$ The Federal Service for Surveillance over Consumer Rights Protection and Human Well-being, Penza Regional \\ Office, 35 Lermontova Str., Penza, 440026, Russian Federation \\ ${ }^{5}$ The Center for Hygiene and Epidemiology in Penza Region, 3 Marshala Krylova Str., Penza, 440026, \\ Russian Federation
}

The paper focuses on morbidity among children that was examined as per medical aid appealability and prevailing behavioral factors among children aged 10-14 who attended schools with different systems for healthy lifestyle creation. In 2008, when a continuous system for healthy lifestyle formation was just being introduced, there were only slight differences in primary and overall morbidity among children aged 10-14 who attended test schools and reference ones; 10 years later, in 2018, primary and overall morbidity was substantially lower among children who attended tests schools than among those who went to reference ones. Primarily, it concerns such «school-induced» diseases as diseases of the eye and adnexa; diseases of the respiratory system; gastric diseases; diseases of the musculoskeletal system and the connective tissue; injury, poisoning and certain other consequences of external causes. Data obtained via questioning that was performed among schoolchildren and concentrated on them assessing their health are well in line with official data on morbidity obtained as per medical aid appealability. Children from test schools estimated their health as poor much less frequently than children from reference schools; they were significantly less irritable, and bad mood was also not so frequent among them.

Healthy lifestyle recommended for children included an obligatory combination of 5 basic components: fruit and vegetables should be consumed every day; sleep should be not shorter than 8 hours; physical activity was to be 1 hour a day or longer not more than 2 hours a day should be spent working or playing on a PC, laptop, or a smartphone; no alcohol intake and no smoking either. Assessment of this lifestyle revealed that a share of children who pursued it was higher in test schools than in reference ones; in the $5-6^{\text {th }}$ grades, $18.7 \pm 1.62 \%$ and $11.0 \pm 1.43 \%(t=3.56)$ accordingly; in the $7-8^{\text {th }}$ grades, $19.2 \pm 2.09 \%$ and $11.8 \pm 1.41 \%(t=2.93)$.

Key words: children, secondary schools, a continuous system for healthy lifestyle formation, morbidity, questioning, health self-assessment, behavioral factors prevalence, healthy habits.

At present primary and secondary prevention unfortunately don't provide the results they should [1]; it is confirmed, among other things, by absence of any positive trends regarding schoolchildren's somatic and mental health [2-4]. Given that, it seems vital to make the school environment a useful resource for improving their health and increasing welfare for everyone $[5,6]$; to achieve that, greater at- tention should be paid to examining and analyzing various factors that provide children's and teenagers' health instead of simple risks reduction [7].

Factors that can be considered as a resource for schoolchildren's health improvement primarily include the following: medical support provided at an educational establishment [8, 9], creating a motivation among

(C) Vasilyev V.V., Perekusikhin M.V., Vasilyev E.V., 2021

Valery V. Vasilyev - Doctor of Medical Sciences, Professor at the Department for Hygiene, Public Health and Public Healthcare (e-mail: vvv1755@yandex.ru; tel.: +7 (909) 316-01-97; ORCID: https://orcid.org/0000-0002-7045-2489).

Mikhail V. Perekusikhin - Supervisor (e-mail: sanepid@sura.ru; tel.: +7 (8412) 55-26-06; ORCID: https://orcid.org/ 0000-0001-7407-9493).

Evgeniy V. Vasilyev - Medical expert on common hygiene (e-mail: vasilev-ev87@mail.ru; tel.: +7 (8412) 56-46-97; ORCID: https://orcid.org/0000-0003-2699-8692). 
schoolchildren to pursue healthy lifestyle [10-13], supporting positive changes in behavior, physical activity, nutrition, and health self-assessment [14, 15].

Sanitary and hygienic education provided by educational establishments (EE) via building up knowledge and convictions, developing abilities and skills to make a choice on healthy behavior can prevent multiple behavioral risk factors from occurring $[10,16]$. A success here depends on interaction between EE and primary medical care [17], families and variable partners [18].

Children should be introduced to preserving and improving their health via creating attitudes towards healthy lifestyle and it should be done staring from early age in the course of their education taking into account peculiarities of their behavioral attitudes towards their own health and places where they live [19-21]. Given that, it seems vital to examine experience gained in organizing an educational process in such a way so that it helps preserve health of schoolchildren who attend secondary schools. It can allow determining what interventions or adjustments are necessary in the sphere.

Our research goal was to comparatively assess two educational processes that were organized in a different way regarding medical support and a system for healthy lifestyle creation.

Data and methods. Our research objects were 6 educational establishments located in Penza city; and schoolchildren who attended these establishments were our units under observation. In accordance with the set goal, we examined morbidity among children in 2008 and 2018 via analyzing data taken from statistical reports (Statistical Form No. 025/u "Medical records of a patient who applies for outpatient care"). We performed a retrospect study of morbidity among children aged 10-14 who attended three test schools (1,087 people in 2008; 1,126 in 2018) and three reference schools (982 and 1,018 people accordingly). Morbidity parameters were calculated as per data on applications for medical aid. In November and December 2018 a questioning was performed at the same schools; a questionnaire consisted of 30 questions on lifestyle, screening assessments of health, and attitudes towards school (as per an international questionnaire entitled Health Behavior in School-aged Children). 1,935 schoolchildren took part in voluntary anonymous questioning; 1,054 out of them attended the test schools (TS) (579 attended the $5-6^{\text {th }}$ grades; $475,7-8^{\text {th }}$ grades $) ; 881$ attended the reference schools (RS) $\left(355\right.$ attended the $5-6^{\text {th }}$ grades; 526 , the $7-8^{\text {th }}$ grades $)$.

The test schools were the Secondary School No. 74, "SAN" Gymnasium, and Gymnasium No. 13; in 2008 prevention and rehabilitation offices were opened in all three of them [22], and in the same year a system for continuous education on healthy lifestyle creation was implemented in the educational processes in all three TS. Schoolchildren got access to health-improving procedures, dentist's aid, and consultations on behavior corrections via visiting a physiotherapeutic or a massage room, training facilities and facilities for exercise therapy that were opened in the $\mathrm{TS}$; it could be done basing on a therapist's recommendations and without any breaks in the educational process. These test schools where medical support, together with conventional medical offices, includes additional prevention and rehabilitation facilities can be considered a resource for health improvement and it allows providing a health-preserving educational process and preserving schoolchildren's health that is ranked among the most important tasks the state has to fulfill [23].

Attitudes towards healthy lifestyle are created among schoolchildren attending the TS basing on interdepartmental interactions and sectoral partnership and with parents actively participating in the process; necessary components in healthy lifestyle creation are built into children's activities during classes, beyond them, and in their project activities (Figure).

In the TS there is a system for continuous education on healthy lifestyle creation including classes on "Healthy lifestyle" in junior 


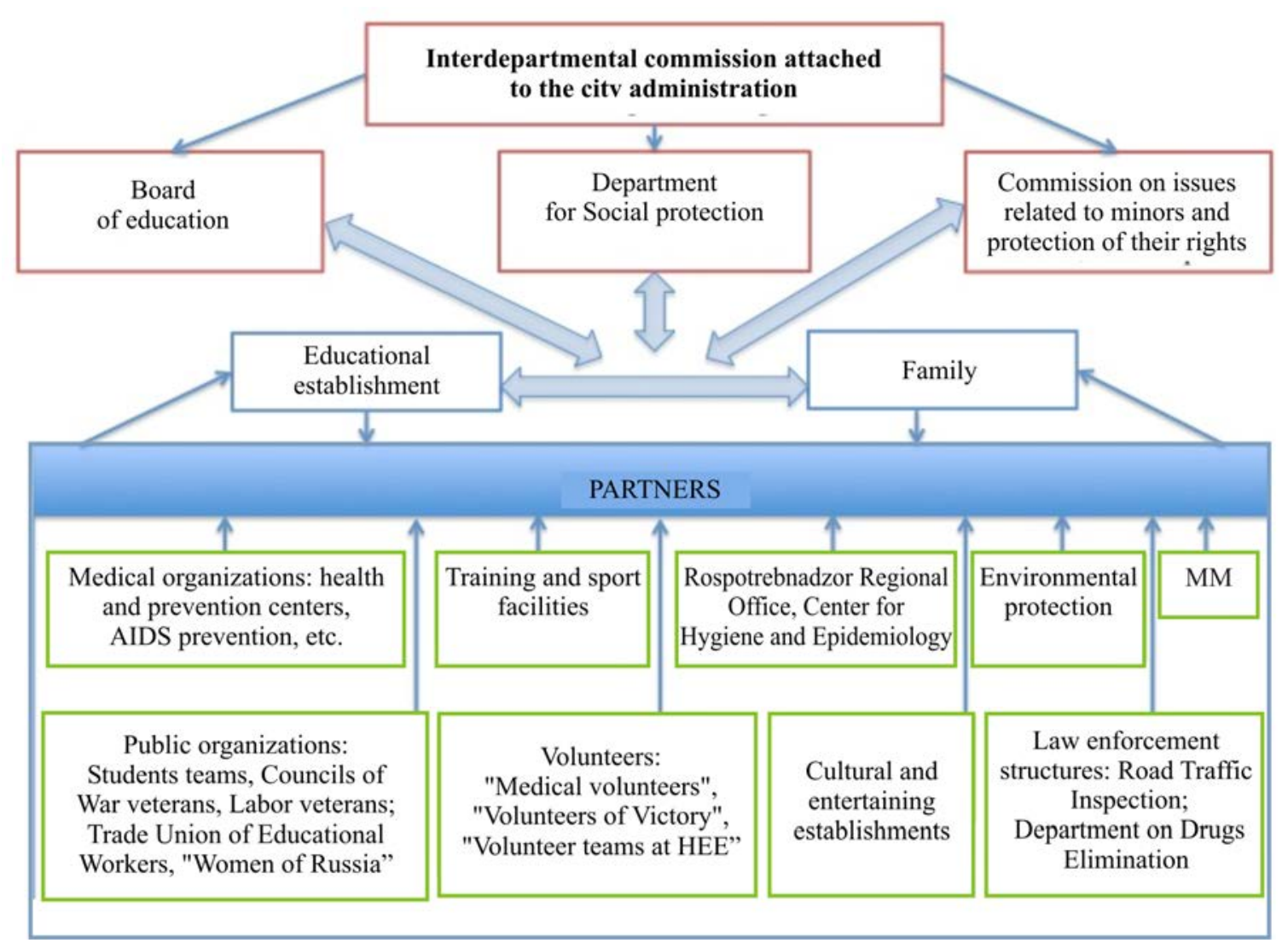

Figure. Interdepartmental interaction and social partnership in creating hygienic culture and healthy lifestyle

and middle grades and "Basics of healthy lifestyle" in senior grades; these classes are taught within a regional component in educational programs. Skills and abilities regarding healthy lifestyle are also trained during lessons in ordinary school subjects such as physical training, biology, chemistry, physics, geography, as well as basics of safe life activities. Continuous education on healthy lifestyle creation is aimed at developing value orientation at health and relevant behavioral stereotypes. Continuous education provided for schoolchildren from the $1^{\text {st }}$ to $11^{\text {th }}$ grade is based on an author's methodology approved by the Penza regional administration and developed by scientists in a close cooperation with experts from Rospotrebnadzor's regional office in Penza and schoolteachers. In 2008-2009 the authors' team created a teaching methodological complex consisting of 11 manuals and textbooks including electronic ones that contained developing and role games. Apart from conventional education techniques, the educational process utilizes variable technologies such as communication, volunteering, and partnership. All this together allows better communication on risk factors for schoolchildren and their parents, teachers, and school personnel and provides motivation and creating conditions for developing skills of healthy lifestyle.

Our reference schools were the Secondary School No. 52, Secondary School No. 56, and Gymnasium No. 42 where the educational process didn't provide available prevention and rehabilitation facilities (medical support at school was provided via conventional medical offices) and there was no continuous education on healthy lifestyle creation.

All six schools were located in the Oktyabrskiy district in the city where there were no industrial enterprises and medical aid for minors was provided at a single polyclinic for children, namely the municipal children's polyclinic No. 6. 
All the data were statistically processed with a statistics calculator. Student's t-test was applied to determine statistical significance of values obtained for the examined samplings.

Results and discussion. Having examined applications for medical aid by children in 2008, we detected that primary morbidity and overall morbidity among children aged 10-14 didn't have authentic differences between the test and reference schools $\left(t_{1}=1.67 ; t_{2}=1.22\right)$. Primary morbidity among children aged 10-14 in 2018 went down authentically against 2008 , both among schoolchildren from the test schools and the reference ones (Table 1). But morbidity growth in 2018 against 2008 amounted to (-6.47\%) among children attending the TS whereas it was only $(-1.37 \%)$ among those attending the RS. Overall morbidity also decreased over 10 years and its growth amounted to ($6.61 \%$ ) among children from the TS and only $(-3.11 \%)$ among those from the RS.

In 2018 primary and overall morbidity were authentically lower among children attending the test schools than among those from the reference ones (Tables 2 and 3 ). Primary morbidity among children attending the test schools was significantly lower than among their counterparts attending the RS as per such nosologies as diseases of the eye and adnexa; diseases of the respiratory system; diseases of the digestive system; diseases of the musculoskeletal system and connective tissue; injury, poisoning and certain other consequences of external causes (Table 2). We didn't reveal any authentic differences in morbidity among children as per other nosologies.

Table 1

Morbidity among children aged 10-14 in 2008 and 2018 (per 1,000 children of the relevant age)

\begin{tabular}{|c|c|c|c|c|c|c|}
\hline \multirow{2}{*}{ Morbidity } & \multicolumn{2}{|c|}{$T S$} & \multirow{2}{*}{$t$} & \multicolumn{2}{|c|}{$R S$} & \multirow{2}{*}{$t$} \\
\cline { 2 - 3 } \cline { 5 - 6 } & 2008 & 2018 & & 2008 & 2018 & \\
\hline Primary & $2,547.43 \pm 60.22$ & $2,382.54 \pm 54.08$ & 15.4 & $2,528.91 \pm 62.75$ & $2,494.31 \pm 60.50$ & 3.1 \\
\hline Overall & $3,056.27 \pm 76.03$ & $2,854.17 \pm 68.65$ & 16.8 & $3,071.52 \pm 80.49$ & $2,976.19 \pm 76.01$ & 7.6 \\
\hline
\end{tabular}

Table 2

Morbidity among children aged 10-14 first detected in their life in 2018

(per 1,000 children of the relevant age)

\begin{tabular}{|l|c|c|c|}
\hline \multirow{2}{*}{ Nosology } & $T S$ & $R S$ & \multirow{2}{*}{$t$} \\
\cline { 2 - 3 } & $M \pm m$ & $M \pm m$ & \\
\hline Diseases cases, overall & $2382.54 \pm 54.08$ & $2494.31 \pm 60.50$ & $10.44^{*}$ \\
\hline Certain infections and parasitic diseases & $69.06 \pm 7.55$ & $67.42 \pm 7.8$ & 0.42 \\
\hline Neoplasms & $4.63 \pm 2.02$ & $5.13 \pm 2.24$ & 0.24 \\
\hline Diseases of the blood and blood-forming organs & $3.46 \pm 1.75$ & $3.86 \pm 1.94$ & 0.20 \\
\hline Endocrine, nutritional, and metabolic disorders & $10.90 \pm 3.09$ & $13.72 \pm 3.64$ & 1.09 \\
\hline Diseases of the nervous system & $29.22 \pm 5.02$ & $30.87 \pm 5.42$ & 0.51 \\
\hline Diseases of the eye and adnexa & $68.16 \pm 7.51$ & $87.03 \pm 8.83$ & $4.67^{*}$ \\
\hline Diseases of the ear and mastoid process & $48.0 \pm 6.37$ & $44.14 \pm 6.44$ & 1.08 \\
\hline Diseases of the circulatory system & $11.25 \pm 3.14$ & $12.98 \pm 3.55$ & 0.67 \\
\hline Diseases of the respiratory system & $1,483.86 \pm 25.25$ & $1,519.26 \pm 27.84$ & $4.86^{*}$ \\
\hline Diseases of the digestive system & $247.77 \pm 12.86$ & $266.53 \pm 13.86$ & $3.63^{*}$ \\
\hline Diseases of the skin and subcutaneous tissue & $61.73 \pm 7.17$ & $62.07 \pm 7.56$ & 0.30 \\
\hline Diseases of the musculoskeletal system and connective tissue & $66.61 \pm 7.43$ & $81.56 \pm 8.58$ & $3.73^{*}$ \\
\hline Diseases of the genitourinary system & $73.02 \pm 7.75$ & $68.13 \pm 7.90$ & 1.23 \\
\hline Congenital malformations & $6.73 \pm 2.43$ & $6.65 \pm 2.58$ & 0.19 \\
\hline Injury, poisoning and certain other consequences of external causes & $198.14 \pm 11.8$ & $224.96 \pm 13.09$ & $5.37^{*}$ \\
\hline
\end{tabular}

$\mathrm{N}$ o t e : here and in the table $3 *$ means there are authentic differences in morbidity among children from the $\mathrm{TS}$ and $\mathrm{RS}(t>2)$. 
Table 3

Overall morbidity among children aged 10-14 in 2018 (per 1,000 children of the relevant age)

\begin{tabular}{|c|c|c|c|}
\hline \multirow{2}{*}{ Nosology } & TS & $R S$ & \multirow{2}{*}{$t$} \\
\hline & $M \pm m$ & $M \pm m$ & \\
\hline Diseases cases, overall & $2.854,17 \pm 68.65$ & $2.976,19 \pm 76.01$ & $10.15^{*}$ \\
\hline Certain infections and parasitic diseases & $88.31 \pm 8.45$ & $79.04 \pm 8.46$ & 1.09 \\
\hline Neoplasms & $7.44 \pm 2.56$ & $8.18 \pm 2.82$ & 0.32 \\
\hline Diseases of the blood and blood-forming organs & $8.08 \pm 2.66$ & $7.59 \pm 2.72$ & 0.21 \\
\hline Endocrine, nutritional, and metabolic disorders & $31.16 \pm 5.18$ & $35.52 \pm 5.80$ & 1.31 \\
\hline Diseases of the nervous system & $41.08 \pm 5.91$ & $45.56 \pm 6.53$ & 1.27 \\
\hline Diseases of the eye and adnexa & $96.47 \pm 8.80$ & $107.17 \pm 9.69$ & $2.48^{*}$ \\
\hline Diseases of the ear and mastoid process & $48.26 \pm 6.38$ & $44.49 \pm 6.46$ & 1.05 \\
\hline Diseases of the circulatory system & $28.09 \pm 4.92$ & $25.38 \pm 4.93$ & 0.86 \\
\hline Diseases of the respiratory system & $1,542.4 \pm 27.25$ & $1,598.59 \pm 30.66$ & $7.38^{*}$ \\
\hline Diseases of the digestive system & $441.36 \pm 14.79$ & $470.14 \pm 15.64$ & $5.22 *$ \\
\hline Diseases of the skin and subcutaneous tissue & $74.18 \pm 7.81$ & $70.56 \pm 8.02$ & 0.91 \\
\hline Diseases of the musculoskeletal system and connective tissue & $96.67 \pm 8.80$ & $111.34 \pm 9.86$ & $3.39 *$ \\
\hline Diseases of the genitourinary system & $130.38 \pm 10.03$ & $121.39 \pm 10.23$ & 1.99 \\
\hline Congenital malformations & $22.15 \pm 4.38$ & $23.28 \pm 4.72$ & 0.37 \\
\hline $\begin{array}{l}\text { Injury, poisoning and certain other consequences of external } \\
\text { causes }\end{array}$ & $198.14 \pm 11.8$ & $224.96 \pm 13.09$ & $5.37^{*}$ \\
\hline
\end{tabular}

Prevalence of such disorders as diseases of the eye and adnexa, diseases of respiratory system, diseases of the digestive system, diseases of the musculoskeletal system and connective tissue, injury, poisoning and certain other consequences of external causes was authentically lower among children who attended the test schools than among those from the reference ones (Table 3 ).

Therefore, school-related diseases were much less frequent in 2018 than in 2008 among children who attended the test schools where a contemporary model of school medical aid was implemented into the educational process starting from 2008 than among those who attended the reference ones. This model envisages opening prevention and rehabilitation facilities at an EE together with a conventional medical office and providing continuous education on healthy lifestyle creation from the $1^{\text {st }}$ to $11^{\text {th }}$ grade. We should note that primary morbidity among children aged 10-14 who are classified as junior teenagers by the World Health Organization was substantially higher than among senior teenagers (aged 15-17); in Penza primary morbidity among the latter amounted to $1,495.2$ and 2,308.7 per 1,000 teenagers of the relevant age on average in 2016 and in
2017. It calls for greater attention being paid to health of children aged 10-14, including studying and analyzing factors that influence their health.

Our questioning revealed that health parameters of children from two compared types of schools had certain differences regarding some questions; thus, $16.4 \%$ children from the $5-6^{\text {th }}$ grades and $18.3 \%$ children from the $7-8^{\text {th }}$ grades in the TS assessed their health rather as "poor" than "satisfactory" and the share of such children was even higher in the RS, $25.6 \%$ and $24.9 \%$ accordingly $(t=3.67$ and $t=2.37)$. Neurotic disorders were more frequent among $5-6^{\text {th }}$ grade children in the RS: one third of them had bad mood or felt irritated more often than one a week whereas it was so only for each forth child in the $5-6^{\text {th }}$ grades in the TS $(t=4.65)$; anxiety appeared in $29.8 \%$ and $24.8 \%$ accordingly $(t<2)$. Each third schoolchild $(33.8 \%)$ from the $7-8^{\text {th }}$ grades in the RS mentioned bad mood and irritability; in the TS, only each forth $(24.4 \%)(t=3.03)$; anxiety was mentioned by $26.0 \%$ and $28.5 \%$ children accordingly $(t<2)$. Gender analysis revealed that girls from the $7-8^{\text {th }}$ grades, both in the TS and RS, tended to have bad moods and headaches and feel irritated more frequently than boys 
$(t=2.19)$; they also gave lower assessments of their health $(t=3.15)$.

Having assessed what complaints about health schoolchildren usually had, we didn't reveal any authentic differences excluding headaches prevalence among children from 5$6^{\text {th }}$ grades, $17.6 \%$ and $22.8 \%(t=2.06)$; overall, regardless of age, almost each fifth child complained about headaches; each tenth had difficulty in falling asleep. Aches in other places were mentioned by $15.7 \%$ children from the $5-6^{\text {th }}$ grades in the TS and $16.9 \%$ in the RS $(t<2) ; 15.4 \%$ and $17.5 \%$ accordingly among children from the $7-8^{\text {th }}$ grades $(t<2)$ (Tables 4 and 5).

Self-assessment of health by children from the $5-6^{\text {th }}$ grades coincided with their mental perception of their school: schoolchildren from the TS had positive attitudes towards school much more frequently $(75.8 \%)$ than their counterparts from the RS $(67.0 \%)$ $(t=3.17)$. Answers to questions regarding difficulties in the educational process differed only slightly between respondents from the TS and RS. Children from the $7-8^{\text {th }}$ grades in both types of schools stated that the educational program was difficult more frequently than children from the $5-6^{\text {th }}$ grades $(t=3.06$ and $t=2.47)$.

Optimal nutrition should always include meat and milk products consumed 5 days a week or more and fruit and vegetables consumed daily. Our questioning results indicate that only two thirds of respondents consumed milk products and meat 5 days a week or more. There were no authentic differences regarding meat and milk products consumption by children form the $5-6^{\text {th }}$ grades in the TS and RS. But a share of children from the $7-8^{\text {th }}$ grades who consumed meat not less than

Table 4

Attitudes to educational activities among children from the $5-6^{\text {th }}$ grades and data on their health and prevalence of factors that influence it, $\%$

\begin{tabular}{|l|c|c|c|}
\hline \multicolumn{1}{|c|}{ Parameters } & $T S$ & $R S$ & $t$ \\
\hline Poor health & $16.40 \pm 1.54$ & $25.63 \pm 2.00$ & $3.67^{*}$ \\
\hline Headaches (more often than once a week) & $17.61 \pm 1.58$ & $22.81 \pm 1.92$ & $2.06^{*}$ \\
\hline Other aches (more often than once a week) & $15.71 \pm 1.51$ & $16.90 \pm 1.72$ & 0.49 \\
\hline Bad mood, irritability (more often than once a week) & $25.56 \pm 1.81$ & $38.87 \pm 2.24$ & $4.65^{*}$ \\
\hline Anxiety (more often than once a week) & $24.87 \pm 1.80$ & $29.86 \pm 2.10$ & 1.82 \\
\hline Insomnia (more often than once a week) & $10.01 \pm 1.25$ & $12.95 \pm 1.54$ & 1.43 \\
\hline Positive attitudes towards school & $75.82 \pm 1.78$ & $67.04 \pm 2.16$ & $3.17^{*}$ \\
\hline Difficulties in studies & $14.16 \pm 1.45$ & $17.46 \pm 1.74$ & 1.46 \\
\hline Everyday breakfast on workdays & $77.20 \pm 1.74$ & $77.75 \pm 1.91$ & 0.19 \\
\hline Hot meals 2 times a day or more & $69.77 \pm 1.91$ & $54.46 \pm 2.28$ & $5.12^{*}$ \\
\hline Fruit consumed every day & $72.54 \pm 1.85$ & $62.25 \pm 2.22$ & $3.53^{*}$ \\
\hline Vegetables consumed every day & $69.95 \pm 1.91$ & $59.72 \pm 2.25$ & $3.45^{*}$ \\
\hline Milk products consumed 5 days a week or more & $67.36 \pm 1.95$ & $63.38 \pm 2.21$ & 1.35 \\
\hline Meat consumed 5 days a week or more & $68.05 \pm 1.94$ & $63.94 \pm 2.19$ & 1.10 \\
\hline Daily physical activities (1 hour and longer) & $67.0 \pm 1.95$ & $54.46 \pm 2.28$ & $4.15^{*}$ \\
\hline Every day sleep for less than 8 hours & $42.66 \pm 2.06$ & $47.89 \pm 2.29$ & 1.67 \\
\hline More than 2 hours every day spent with a PC or a gadget & $51.64 \pm 2.08$ & $56.34 \pm 2.28$ & 1.55 \\
\hline Smoking every week & $1.38 \pm 0.49$ & $4.22 \pm 0.92$ & $2.72^{*}$ \\
\hline Drinking beer every week & $1.9 \pm 0.57$ & $2.82 \pm 0.75$ & 0.89 \\
\hline Drinking strong spirits every week & $1.21 \pm 0.45$ & $1.97 \pm 0.63$ & 0.89 \\
\hline Participating in fights over the previous year & $23.66 \pm 1.64$ & $23.67 \pm 1.95$ & 1.66 \\
\hline Bullied their classmates over the last 3 months & $19.17 \pm 1.64$ & $21.97 \pm 1.90$ & 1.09 \\
\hline Were victims of bullying in school & $18.65 \pm 1.62$ & $21.13 \pm 1.87$ & 0.97 \\
\hline
\end{tabular}

$\mathrm{N}$ ot e : here and then in Table $5 *$ means there are authentic differences between answers given by respondents from the TS and RS $(t>2)$; 
Table 5

Attitudes to educational activities among children from the $7-8^{\text {th }}$ grades and data on their health and prevalence of factors that influence it, $\%$

\begin{tabular}{|c|c|c|c|}
\hline Parameters & TS & $R S$ & $t$ \\
\hline Poor health & $18.31 \pm 2.05$ & $24.90 \pm 1.89$ & $2.37 *$ \\
\hline Headaches (more often than once a week) & $16.74 \pm 1.98$ & $19.23 \pm 1.72$ & 0.99 \\
\hline Other aches (more often than once a week) & $15.47 \pm 1.92$ & $17.56 \pm 1.66$ & 0.79 \\
\hline Bad mood, irritability (more often than once a week) & $24.47 \pm 2.28$ & $33.84 \pm 2.06$ & $3.03 *$ \\
\hline Anxiety (more often than once a week) & $26.07 \pm 2.33$ & $28.52 \pm 1.97$ & 0.85 \\
\hline Insomnia (more often than once a week) & $10.10 \pm 1.60$ & $12.23 \pm 1.43$ & 0.94 \\
\hline Positive attitudes towards school & $75.47 \pm 2.28$ & $73.54 \pm 1.92$ & 0.64 \\
\hline Difficulties in studies & $22.26 \pm 2.21$ & $23.89 \pm 1.86$ & 0.59 \\
\hline Everyday breakfast on workdays & $76.84 \pm 2.24$ & $64.83 \pm 2.08$ & $3.95 *$ \\
\hline Hot meals 2 times a day or more & $66.74 \pm 2.50$ & $60.84 \pm 2.13$ & 1.8 \\
\hline Fruit consumed every day & $79.58 \pm 2.15$ & $59.70 \pm 2.14$ & $6.52 *$ \\
\hline Vegetables consumed every day & $74.74 \pm 2.31$ & $60.46 \pm 2.13$ & $4.52 *$ \\
\hline Milk products consumed 5 days a week or more & $66.32 \pm 2.51$ & $67.30 \pm 2.13$ & 1.74 \\
\hline Meat consumed 5 days a week or more & $66.53 \pm 2.51$ & $56.84 \pm 2.16$ & $2.91 *$ \\
\hline Daily physical activities (1 hour and longer) & $42.68 \pm 2.62$ & $35.70 \pm 2.09$ & $2.03 *$ \\
\hline Every day sleep for less than 8 hours & $50.99 \pm 2.65$ & $56.27 \pm 2.16$ & 1.54 \\
\hline More than 2 hours every day spent with a PC or a gadget & $51.83 \pm 2.65$ & $58.94 \pm 2.15$ & $2.08 *$ \\
\hline Smoking every week & $2.21 \pm 0.79$ & $5.09 \pm 0.96$ & $2.32 *$ \\
\hline Drinking beer every week & $2.8 \pm 0.88$ & $3.80 \pm 0.83$ & 0.81 \\
\hline Drinking strong spirits every week & $1.64 \pm 0.68$ & $2.17 \pm 0.62$ & 0.43 \\
\hline Participating in fights over the previous year & $16.84 \pm 1.99$ & $23.73 \pm 1.86$ & $2.52 *$ \\
\hline Bullied their classmates over the last 3 months & $14.31 \pm 1.86$ & $22.51 \pm 1.82$ & $3.10 *$ \\
\hline Were victims of bullying in school & $14.53 \pm 1.86$ & $15.32 \pm 1.57$ & 0.42 \\
\hline
\end{tabular}

5 days a week was substantially higher in the TS than in the RS, $66.5 \%$ and $56.8 \%$ accordingly $(t=2.91)$. Children from the TS consumed fruit more frequently than their counterparts from the RS: $72.5 \%$ and $62.2 \%$ accordingly in the $5-6^{\text {th }}$ grades $(t=3.53)$ and $79.5 \%$ and $59.7 \%$ in the $7-8^{\text {th }}$ grades $(t=6.52)$; and vegetables, $69.9 \%$ and $59.7 \%$ in the $5-6^{\text {th }}$ grades $(t=3.45)$ and $74.7 \%$ and $60.4 \%$ in the $7-8^{\text {th }}$ grades $(t=4.52)$. When fruit and vegetables are not consumed in sufficient quantities, it can result in so called latent hunger or micronutrients deficiency and cause a risk of cardiovascular diseases, cancer, diabetes, and obesity. Children from the $7-8^{\text {th }}$ grades in the TS had breakfast on workdays more frequently than their counterparts from the RS, $76.8 \%$ against $64.8 \%(t=3.95)$. A share of schoolchildren from the $5-6^{\text {th }}$ grades who had breakfast every day on workdays didn't differ between the compared schools. A number of schoolchildren from the $5-6^{\text {th }}$ grades who had hot meals 2 times a day or more was signifi- cantly higher among children from the TS than RS, $69.7 \%$ and $54.4 \%$ accordingly $(t=5.12)$. A share of schoolchildren from the $7-8^{\text {th }}$ grades who had hot meals 2 times a day or more amounted to $66.7 \%$ in the TS and $60.8 \%$ in the RS $(t<2)$.

Health of children in puberty is influenced significantly by such behavioral factors as intensity of physical activity, amount of time spent with a PC or a gadget, and amount of sleep [17, 24]. There were significantly more children with moderate physical activity (not less than 1 hour a day) in the TS than in the RS: $5-6^{\text {th }}$ grades, $67.0 \%$ and $54.4 \%$ accordingly $(t=4.15)$; the $7-8^{\text {th }}$ grades, $42.6 \%$ and $35.7 \%(t=2.03)$. A share of children with daily physical activity being longer than 1 hour was lower among children from the $7-8^{\text {th }}$ grades than among those from the $5-6^{\text {th }}$ grades in both types of $\mathrm{EE}(t=7.39$ and $t=6.07$ accordingly). Each second schoolchild spent more than 2 hours with a PC or any other digital device. A difference in this 
parameter was only slight for children from the $5-6^{\text {th }}$ grades but it was authentic for children from the $7-8^{\text {th }}$ grades, $51.8 \%$ in the TS and $58.8 \%$ in the $\mathrm{RS}(t=2.08)$. Each second child from the $7-8^{\text {th }}$ grades, $51 \%$ in the TS and $56.3 \%$ in the RS slept for less than 8 hours and it was authentically different from figures obtained for children from the $5-6^{\text {th }}$ grades, $42.6 \%$ and $47.8 \% \quad(t=2.48$ and $t=2.69)$.

Our study on behavioral risk factors revealed that more children from the TS smoked every week against the same parameter in the RS, accordingly in the $5-6^{\text {th }}$ grades $(t=2,72)$; in the $7-8^{\text {th }}$ grades, $(t=2.32)$. We didn't reveal any authentic differences as per weekly intake of beer or strong spirits in two compared types of schools.

The data on health and prevalence of factors that influence it as well as on schoolchildren's attitudes towards school studies that we obtained via questioning schoolchildren in Penza predominantly coincide with data obtained via questioning performed by S.B. Sokolova among schoolchildren from $7-8^{\text {th }}$ grades in Moscow [25].

Aggressive behavior that is typical for two out of ten respondents is rather alerting. Schoolchildren from the $7-8^{\text {th }}$ grades in the RS participated in fights $(t=2.52)$ and bullied their classmates $(t=3.10)$ more frequently than their counterparts from the TS. Meanwhile, health self-assessment, contentment with life, and subjective complaints about one's health are closely connected with psychosocial environment at school and relationships between classmates [19, 26]. As per data obtained via questioning, $81.7 \%$ schoolchildren from the $5-6^{\text {th }}$ grades in the TS and $72.2 \%$ in the RS $(t=3.63)$ were quite content with their life; $77.9 \%$ and $70.4 \%$ accordingly in the $7-8^{\text {th }}$ grades $(t=2.59)$. As it has already been mentioned, health self-assessment was higher among children who attended the TS and they had subjective complaints less frequently than their counterparts from the RS. It indicates that psychosocial environment at school plays an exceptionally vital role in maintaining children's health and it is advis- able to examine it in detail when characterizing schoolchildren's health.

Healthy lifestyle that children should pursue involves daily consumption of fruit and vegetables, night sleep lasting not less than 8 hours, physical activity for not less than 1 hour a day, time spent with a $\mathrm{PC}$ or any other electronic device not exceeding 2 hours, and total abstention from alcohol and smoking. Having performed complex assessment of children's actual lifestyles, we revealed that a number of children who adhered to all the above-mentioned behavior patterns was significantly higher in the TS than in the RS: $18.7 \pm 1.62 \%$ and $11.0 \pm 1.43 \%$ accordingly in the $5-6^{\text {th }}$ grades $(t=3.56)$; $19.2 \pm 2.09 \%$ and $11.8 \pm 1.41 \%$ accordingly in the $7-8^{\text {th }}$ grades $(t=2.93)$. These parameters obtained via questioning performed among schoolchildren in Penza differ from results obtained via questioning performed among junior schoolchildren in Europe and America where only about $5 \%$ children aged 11 and 35 children aged 13 adhered to all 5 above mentioned components of healthy lifestyle every day [20, 27].

Conclusion. Our research allowed determining that implementation of a new model for school medicine and a system of continuous education on healthy lifestyle creation into the educational process in a secondary school yielded certain positive results. Thus, 10 years after the system for healthy lifestyle creation had been implemented there were more children aged 10-14 pursuing healthy lifestyle in the test schools than in the reference ones. It concerned nutrition in particular since there was a greater share of children who had breakfast every day on workdays, had hot meals two times a day or more and consumed fruit and vegetables in the test schools. The share of children who had physical activities for 1 hour a day or longer was also higher in the tests schools; and the share of children with such behavioral risk as tobacco smoking was lower among them. Aggressive behavior was equally frequent among children from the $5-6^{\text {th }}$ grades in both types of schools, but the share of such children was authentically lower in the 
$7-8^{\text {th }}$ grades in the test schools than in the reference ones.

An increase in number of children who pursued healthy lifestyle allowed achieving prevention effects that became apparent via a decrease in morbidity. Thus, in 2008 there was only slight difference in primary morbidity among children aged 10-14 from both test and reference schools; in 2018 morbidity among children who attended the TS was significantly lower than among their counterparts from the RS. We detected authentic differences in primary and overall morbidity among children from the compared groups as per such schoolrelated diseases as diseases of the eye and adnexa, diseases of the respiratory system, diseases of the digestive system, diseases of the musculoskeletal system and connective tissue, injury, poisoning, and certain other consequences of external causes. Data obtained via questioning schoolchildren regarding their health coincided with morbidity that was officially registered as per applications for medical aid: children from the TS assessed their health as poor much less frequent that their counterparts from the RS, they also had bad mood and got irritated less frequently; children from the $5-6^{\text {th }}$ grades in the TS complained about headaches more rarely.

Healthy lifestyle includes 5 obligatory components that should be pursued: daily physical activity for not less than 1 hour, night sleep being not less than 8 hours, daily consumption of fruit and vegetables, less than 2 hours spent every day with a PC or any other electronic device, and total abstention from alcohol and tobacco. Having assessed actual children's lifestyle, we revealed that there were still a lot of reserves for preserving children's health due to potential decrease in morbidity since a share of children who pursued healthy lifestyle in its integrity as a combination of 5 basic components was rather low even in the test schools, namely $18.7 \pm 1.62 \%$ of children from the $5-6^{\text {th }}$ grades and $19.2 \pm 2.09 \%$ among children from the $7-8^{\text {th }}$ grades. It was even lower in the reference schools, $11.0 \pm 1.43 \%$ and $11.8 \pm 1.41 \%$ accordingly.

\section{Conclusions:}

1. When a system for continuous education on healthy lifestyle formation was implemented into the educational process at secondary schools via opening prevention and rehabilitation facilities in them, it resulted in an increase in a share of children who pursued healthy lifestyle and a decrease in a share of children with risky behavior. It allowed achieving prevention effects that became apparent via a significant decrease in primary and overall morbidity, predominantly with school-related diseases, taken in dynamics over 10 years.

2. In order to preserve schoolchildren's health, it is advisable to use this experience of opening prevention and rehabilitation facilities and implementing a system for continuous education on healthy lifestyle creation in other cities in the region and other regions in the country as well.

Funding. The research was not granted any sponsor support.

Conflict of interests. The authors declare there is no any conflict of interests.

\section{References}

1. Kuchma V.R. Hygiene of children and adolescents: personalized and population-based approach to sanitary and epidemiological wellbeing of a young generation in modern conditions. Gigiena i sanitariya, 2019, vol. 98, no. 1, pp. 61-67 (in Russian).

2. Baranov A.A., Al'bitskii V.Yu. State of health of children in Russia, priorities of its preservation and improving. Kazanskii meditsinskii zhurnal, 2018, vol. 99, no. 4, pp. 698-705 (in Russian).

3. Kuchma V.R., Sukhareva L.M., Rapoport I.K., Shubochkina E.I., Skoblina N.A. Population health of children, risks to health and sanitary and epidemiological wellbeing of students: problems, ways of solution and technology of the activity. Gigiena $i$ sanitariya, 2017, vol. 96, no. 12, pp. 990-995 (in Russian).

4. Potrebny T., Wiium N., Haugstvedt A., Sollesnes R., Torsheim T., Wold B., Thuen F. Health complaints among adolescents in Norway: A twenty-year perspective on trends. PloS One, 2019, vol. 14, no. 1, pp. e0210509. DOI: 10.1371/journal.pone.0210509 
5. Promoting intersectoral and interagency action for health and well-being in the WHO European Region: working together for better health and well-being. Meeting Report. Copenhagen, WHO Regional Office for Europe Publ., 2017, 74 p.

6. Chester K.L., Klemera E., Magnusson J., Spencer N.H., Brooks F.M. The role of school-based health education in adolescent spiritual moral, social and cultural development. Health Education Journal, 2019, vol. 78, no. 5, pp. 582-594. DOI: 10.1177/0017896919832341

7. Viner R.M., Ozer E.M., Denny S., Marmot M., Resnick M., Fatusi A., Currie C. Adolescence and the social determinants of health. Lancet, 2012, vol. 379, no. 9826, pp. 1641-1652. DOI: 10.1016/S0140-6736(12)60149-4

8. Baranov A.A., Kuchma V.R., Anufriev E.V., Sokolova S.B., Skoblina N.A., Virabova A.R. Quality evaluation of healthcare services in schools. Vestnik Rossiiskoi akademii meditsinskikh nauk, 2017, vol. 72, no. 3, pp. 180-194 (in Russian).

9. Mann M.J., Smith M.L., Kristjansson A.L., Smith M.L., Daily S.M., Thomas S., Murray S. From Tactics to Strategy: Creating and Sustaining Social Conditions That Demand and Deliver Effective School Health Programs. Journal of School Health, 2018, vol. 88, no. 5, pp. 333-336. DOI: 10.1111/josh.12614

10. Sukharev A.G., Stan V.V., Ignatova L.F. The role of educational organizations in the development of students' motivation to health and healthy lifestyle. Voprosy shkol'noi i universitetskoi meditsiny i zdorov'ya, 2016, no. 2, pp. 32-35 (in Russian).

11. Marques A., Peralta M., Santos T., Martins J., de Matos M.G. Self-rated health and health-related quality of life are related with adolescents' healthy lifestyle. Public health, 2019, vol. 170, pp. 89-94. DOI: $10.1016 /$ j.puhe.2019.02.022

12. Moreno-Maldonado C., Ramos P., Moreno C., Francisco R. How family socioeconomic status, peer behaviors, and school-based intervention on healthy habits influence adolescent eating behaviors. School Psychology International, 2018, vol. 39, no. 1, pp. 92-118. DOI: 10.1177/01430343177499888

13. Park A., Eckert T.L., Zaso M.J., Scott-Sheldon L.A.J., Vanable P.A., Carey K.B., Ewart C.K., Carey M.P. Associations Between Health Literacy and Health Behaviors Among Urban High School Students. Journal of School Health, 2017, no. 12, pp. 885-893. DOI: 10.1111/josh.12567

14. Asigbee F.M., Whitney S.D., Peterson C.E. The Link Between Nutrition and Physical Activity in Increasing Academic Achievement. Journal of School Health, 2018, vol. 88, no. 6, pp. 407-415. DOI: 10.1111 josh.12625

15. Dauenhauer B., Keating X., Stoepker P., Knipe R. State Physical Education Policy Changes From 2001 to 2016. Journal of School Health, 2019, vol. 89, no. 6, pp. 485-493. DOI: 10.1111/josh.12757

16. Patton G.C., Sawyer S.M., Santelli J.S., Ross D.A. Our future: A Lancet commission on adolescent health and wellbeing. Lancet, 2016, vol. 387, no. 10036, pp. 2423-2478. DOI: 10.1016/S01406736(16)00579-1

17. Baltag V., Pachyna A., Hall J. Global overview of school health services: data from 102 countries. Health Behav Policy Rev, 2015, vol. 2, no. 14, pp. 268-283. DOI: 10.14485/HBPR.2.4.4

18. Okely A.D., Hammersley M.L. School-home partnerships: the missing piece in obesity prevention? Lancet Child Adolesc \& Health, 2018, vol. 2, pp. 5-6. DOI: 10.1016/S2352-4642(17)301542(1):5-6

19. Fisenko A.P., Kuchma V.R., Kuchma N.Yu., Naryshkina E.V., Sokolova S.B. Strategy and practice of the forming a healthy lifestyle for children in the Russian Federation. Rossiiskii pediatricheskii zhurnal, 2020, vol. 23, no. 2, pp. 76-84 (in Russian).

20. Marques A., Loureiro N., Avelar-Rosa B., Naia A., Matos M.G. Adolescents' healthy lifestyle. J Pediatr (Rio J), 2020, vol. 96, no. 2, pp. 217-224. DOI: 10.1016/j.jped.2018.09.002

21. Belcastro P.A., Ramsaroop-Hansen H. Addressing the Antinomy Between Health Education and Health Literacy in Advancing Personal Health and Public Health Outcomes. Journal of School Health, 2017, no. 12, pp. 968-974. DOI: org/10.1111/josh.12570

22. Rabota otdelenii profilaktiki i reabilitatsii $\mathrm{v}$ penzenskikh shkolakh yavlyaetsya unikal'nym rossiiskim proektom [Functioning prevention and rehabilitation departments in schools in Penza are a unique Russian project]. Bezformata. Available at: https://penza.bezformata.com/listnews/otdelenijprofilaktiki-i-reabilitatcii/5631721/ (21.05.2020). 
23. Morozov D. Meditsinskaya sostavlyayushchaya v shkole nuzhdaetsya v usilenii [Medical component in school education needs to be enhanced]. Edinaya Rossiya. Available at: https://er.ru/activity/news/ dmitrij-morozov-medicinskaya-sostavlyayushaya-v-shkole-nuzhdaetsya-v-usilenii (11.10.2020).

24. Vandendriessche A., Ghekiere A., Cauwenberg J.V., De Clercq B., Dhondt K., DeSmet A., Tynjälä J., Verloigne M., Deforche B. Does Sleep Mediate the Association between School Pressure, Physical Activity, Screen Time, and Psychological Symptoms in Early Adolescents? A 12-Country Study. Int. J. Environ. Res Public Health, 2019, vol. 16, no. 6, pp. 1072-1116. DOI: 10.3390/ijerph16061072

25. Sokolova S.B. The prevalence of behavioral risk factors, determining health state, among Moscow schoolchildren of 7-8 and 10-11 grades. Zdorov'e naseleniya i sreda obitaniya, 2018, vol. 305, no. 8, pp. 4-10 (in Russian)

26. Markkanen I., Välimaa R., Kannas L. Associations between Students' Perceptions of the Psychosocial School Environment and Indicators of Subjective Health in Finnish Comprehensive Schools. Children and Society, 2019, vol. 33, no. 5, pp. 488-502. DOI: 10.1111/chso.12334

27. Marques A., Bordado J., Tesler R., Demetriou Y., Sturm D.J., de Matos M.G. A composite measure of healthy lifestyle: A study from 38 countries and regions fromde Europe and North America, from the Health Behavior in School-Aged Children survey. American Journal of Human Biology, 2020, vol. 32, no. 6, pp. e23419. DOI: 10.1002/ajhb.23419

Vasilyev V.V., Perekusikhin M.V., Vasilyev E.V. A system for creating healthy lifestyle in educational establishments as a way to prevent health disorders in children. Health Risk Analysis, 2021, no. 2, pp. 72-82. DOI: 10.21668/health.risk/2021.2.07.eng

Received: 03.02.2021

Accepted: 11.06.2021

Published: 30.09.2021 